\title{
Innovation-driven growth in the regions of the Russian federation and the activities of national research universities: analysis of relationship
}

\section{Crescimento impulsionado pela inovação nas regiões da federação russa e as atividades das universidades de pesquisa nacionais: análise do relacionamento}

\section{Crecimiento impulsado por la innovación en las regiones de la federación de rusia y las actividades de las universidades acionales de investigación: análisis de la relación}

\author{
Irina Stanislavovna Glebova1 ${ }^{\text {(D) }}$, Svetlana Sergeevna Berman² iD, \\ Ruslan Agarunovich Abramov ${ }^{3}$ iD, Ilya Nikolaevich Lvov² iD
}

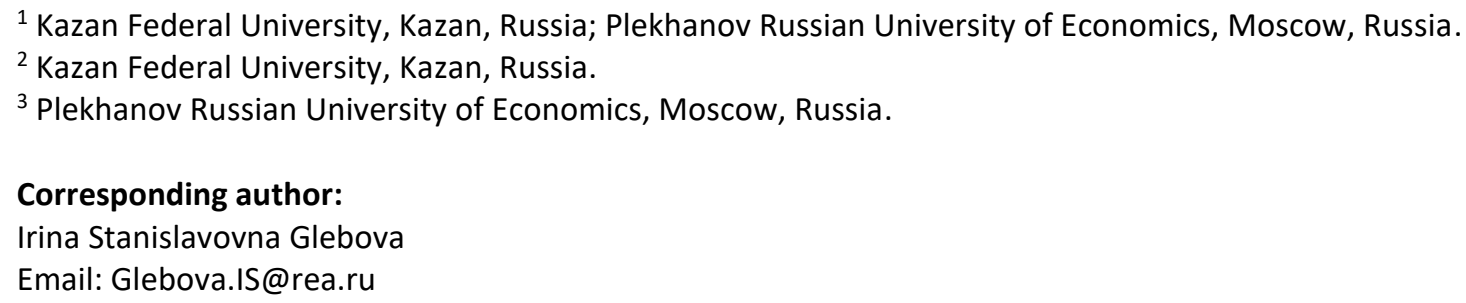

How to cite: Glebova, I. S., Berman, S. S., Abramov, R. A., \& Lvov, I. N. (2021). Innovation-driven growth in the regions of the Russian federation and the activities of national research universities: analysis of relationship. Revista Tempos $e$ Espaços em Educação, 14(33), e15523. http://dx.doi.org/10.20952/revtee.v14i33.15523

\begin{abstract}
The university funding programs focused on regional economic development and "smart specialization" goals are focused on "discovering entrepreneurial potential", which employs the instrument of a structured dialogue among four key actors in the innovation process: public authorities, business structures, research organizations, and representatives of the civil society. The authors analyze the relationship between the results of the activities of national research universities (NRUs) in Russia and the dynamics of innovation-driven growth of the regions in which they are located, based on their methods. The purpose of the study is to search for new tools for interaction between universities and actors of regional innovation-driven growth.
\end{abstract}

Keywords: Income from off-budget activities. Innovation-driven growth of the region. Integral index of innovation-driven growth. National research university. Small innovative enterprises.

\section{RESUMO}

Os programas de financiamento universitário com foco no desenvolvimento econômico regional e nos objetivos de "especialização inteligente" estão focados na "descoberta do potencial 
empreendedor", que utiliza o instrumento de um diálogo estruturado entre quatro atores-chave no processo de inovação: autoridades públicas, estruturas empresariais, organizações de pesquisa e representantes da sociedade civil. Os autores analisam a relação entre os resultados das atividades das universidades nacionais de pesquisa (NRUs) na Rússia e a dinâmica de crescimento impulsionado pela inovação das regiões em que estão localizadas, com base em seus métodos. 0 objetivo do estudo é buscar novas ferramentas de interação entre universidades e atores de crescimento impulsionado pela inovação regional.

Palavras-chave: Crescimento da região impulsionado pela inovação. Índice integral de crescimento impulsionado pela inovação. Pequenas empresas inovadoras. Receita de atividades fora do orçamento. Universidade Nacional de Pesquisa.

\section{RESUMEN}

Los programas de financiación universitaria centrados en el desarrollo económico regional y los objetivos de "especialización inteligente" se centran en "descubrir el potencial empresarial", que emplea el instrumento de un diálogo estructurado entre cuatro actores clave en el proceso de innovación: autoridades públicas, estructuras empresariales, organizaciones de investigación, y representantes de la sociedad civil. Los autores analizan la relación entre los resultados de las actividades de las universidades nacionales de investigación (NRU) en Rusia y la dinámica de crecimiento impulsado por la innovación de las regiones en las que se encuentran, en función de sus métodos. El propósito del estudio es buscar nuevas herramientas de interacción entre universidades y actores del crecimiento regional impulsado por la innovación.

Palabras clave: Crecimiento de la región impulsado por la innovación. Índice integral de crecimiento impulsado por la innovación. Ingresos por actividades extrapresupuestarias. Pequeñas empresas innovadoras. Universidad Nacional de Investigaciones.

\section{INTRODUCTION}

The Russian education system lived through a period of massive transformations less than two decades ago. These transformations were firstly due to the decision of the Government of the Russian Federation to modernize the higher education system in accordance with the requirements of the Bologna Agreement signed in September 2003. Based on this decision, most Russian universities switched to a two-tier education system.

The adoption of the Federal Law No. 273 "On Education in the Russian Federation" in 2012 was the next stage that determined fundamental changes in the higher education system. Under this law, all educational organizations of higher professional education are divided into the following types: a university, an academy, or an institute. At the same time, educational organizations providing services in the field of higher education may be assigned categories such as "federal university" or "national research university" (NRU).

NRUs represent the implementation of a new approach to the innovative process of improving education and updating the form of organization that is engaged in scientific and educational activities. The NRUs were created in order to accommodate the main burden in the personnel and scientific support of the high-tech sectors of the economy in the Russian regions. The specific tasks of the NRUs include the ability not only to generate the knowledge people need, but also to ensure an efficient exchange of technologies, as well as to arrange their activities in close cooperation with the real sector for the dynamic innovation-driven growth of the region.

The purpose of this study is to analyze the relationship between the innovation-driven growth of Russian regions and the activities of research institutions located on their territory in 2013 - 2018. The authors base their conclusions on the outcomes of researching the development of five NRUs: the Kazan National Research Technological University, the Perm State National Research University, the Irkutsk National Research Technical University, the Tomsk Polytechnic University, 
and the Belgorod State National Research University, as well as on the assessment of the innovationdriven growth of the regions they are located in.

The role of universities in the classical Humboldt model was to provide intellectual freedom and conduct objective research independent of markets and governments. Universities evolve, and modern types of universities appear under the influence of new social and economic challenges. The researchers define a university of regional development (Goddard \& Chatterton, 1999), a university of regional cooperation (Holland, 2001), a university of regional innovation organization (Etzkowitz et al., 2000), and a university of academic entrepreneurship (Etzkowitz \& Leydesdorff, 1999). The participation of universities in the development of regions is based on their significant role and the functioning of real mechanisms. Firstly, universities are the main employers and buyers (consumers) of services and goods in the regional market. Secondly, they influence the local labor market through educating personnel for the region. Thirdly, academic entrepreneurship contributes to the creation of new highly potential firms in the region (Power \& Malmberg, 2008). E. Uyarra (2010) singles out the following main channels through which the university develops regional influence: the knowledge factory - the university puts the region in an exceptional position in terms of opportunities for the transfer of knowledge and the pool of human capital at the local level; a starting point for collaboration with regional firms or other local actors unavailable elsewhere; a potential center of academic entrepreneurship - the university activates the entrepreneurial climate in the region and promotes the creation of startups and the introduction of know-how; a breaker of stereotypes and outdated views that hinder cooperation and adaptation of knowledge in the region; and complicity - a university with a regional identity, which deliberately strives for the role of an active supporter of development processes in the region.

It is stated in the concept of an entrepreneurial university (Etzkowitz et al., 2000; Etzkowitz \& Leydesdorff, 1999; Gunasekara, 2006) that universities are increasingly complementing their traditional missions (research and teaching) with the third mission - economic development. Universities promote regional development by actively participating in the commercialization of their knowledge through issuing patents and licensing (Goldstein, 2010). The success of universities in the commercialization of science depends not only on factors inherent in universities, but also on the regional environment (more precisely, on the structure of regional social networks) (Casper, 2013).

Universities play a fundamental role in interactive innovation processes today (Cooke, 2008; Gibbons et al., 1994; Trippl et al., 2015). They are key actors in the knowledge infrastructure in the region. The concept of a regional innovation system focuses on their interactions with other actors and how these interactions lead to regional systemic innovations. In this model, universities are important producers of knowledge that can play the role of a link in the innovation and production sector at the regional level. Similar to the entrepreneurial university model, the regional innovation system approach emphasizes the exchange of knowledge between universities and industry. However, unlike the previous one, it is not only focused on commercialization, but also considers for a much wider set of knowledge transfer mechanisms. These include contract research, formal R\&D collaborations, and forms of knowledge transfer that do not involve financial compensation for universities, such as knowledge transfer (for example, by supplying graduates to the local labor market) and informal contacts with firms. The latter are more common than patents and licenses. In this model, the university's contribution depends on the existing structures of the regional innovation system, the dominant direction of growth, and the prevailing knowledge bases.

\section{METHODOLOGY}

The authors developed the following method to assess the relationship between the innovation-driven growth of Russian regions and the performance of NRUs on their territory from 2013 to 2018: 
At the first stage of the study, indicators were selected that described several areas influencing the innovation-driven growth of the region from 2013 to 2018: the development of human resources for science and innovation in the region $\left(I_{1}\right)$; technical and economic conditions for innovative activities $\left(I_{2}\right)$; the efficiency of innovative activities in the region $\left(I_{3}\right)$; and the level of development of small innovative enterprises $\left(I_{4}\right)$.

The index was calculated in several stages; the values selected for calculating the integral index of the regional development were reduced to comparable ones by switching from their absolute values using the following formula:

$$
\mathrm{X}_{\mathrm{H}}=\left(\mathrm{X}-\mathrm{X}_{\min }\right) /\left(\mathrm{X}_{\max }-\mathrm{X}_{\min }\right)
$$

Where $X n$ was the normalized value of the indicator; $X$ was the actual value of the indicator; Xmin was the lowest value of the indicator for all regions of the Russian Federation; and Xmax was the highest value of the indicator in all regions of the Russian Federation.

The index values for the block were also calculated based on reducing the normalized values to the arithmetic mean, using the following formula:

$$
\mathrm{I}_{n}=1 / \mathrm{n} \sum_{\mathrm{i}=1}^{\mathrm{n}} \frac{\mathrm{x}-\mathrm{x}_{\min }}{\mathrm{x}_{\max }-\mathrm{X}_{\min }}
$$

Where In was the calculated index of the region under consideration for the reporting year in the block; $n$ was the number of indicators in the block; $X$ was the actual value of the indicator; Xmin was the lowest value of the indicator for all regions of the Russian Federation; and Xmax was the highest value of the indicator in all regions of the Russian Federation.

The integral index of the innovation-driven growth in the region was calculated using the values of the indices obtained in each block of indicators. The values calculated by dividing the number of indicators in the block by the total number of indicators used in calculating the index of the innovation-driven growth in the region were used as the weight coefficients of the thematic blocks as follows:

$$
\mathrm{I}=\frac{\mathrm{n}_{\mathrm{I}_{1}}}{\mathrm{~N}} \times \mathrm{I}_{1}+\frac{\mathrm{n}_{\mathrm{I}_{2}}}{\mathrm{~N}} \times \mathrm{I}_{2}+\frac{\mathrm{n}_{\mathrm{I}_{3}}}{\mathrm{~N}} \times \mathrm{I}_{3}+\frac{\mathrm{n}_{\mathrm{I}_{4}}}{\mathrm{~N}} \times \mathrm{I}_{4}
$$

Where I was the integral innovation index of the regional development; $l_{1}$ was the index of innovation-driven growth in the region for the block "Development of human resources for science and innovation in the region"; $I_{2}$ was the index of innovation-driven growth in the region for the block "Technical and economic conditions for innovative activities"; $I_{3}$ was the index of innovationdriven growth in the region for the block "Efficiency of innovative activities in the region"; $I_{4}$ was the index of innovation-driven growth in the region for the block "Level of development of small innovative enterprises"; NIn was the number of indicators in the block; and N was the total number of indicators in the regional innovation index assessment system.

Due to the specifics of publications of state statistics data necessary for calculating the block "Level of development of small innovative enterprises" $\left(I_{4}\right)$, the intermediate results of the integral innovation index of the regional development can only be compared for odd years, i.e., for 2013, 2015 , and 2017, respectively. In this regard, the innovation index of the regional development was additionally calculated without taking the block "Level of development of small innovative enterprises" into account $\left(\mathrm{I}_{4}\right)$.

The next stage of the study was the correlation analysis and calculation of the coefficient of determination as part of this analysis, which allowed to assess what proportion of the resulting attribute $(Y)$ was explained by the influence of independent variables $(X)$. The indicators describing the performance of five NRUs are reflected in the aggregate of independent variables from 2013 to 2018, which include:

- Number of university students, people $\left(X_{1}\right)$;

- Number of graduate students, people $\left(X_{2}\right)$;

- Volume of R\&D, rub. $\left(X_{3}\right)$;

- Number of patents received by the university in the reporting year, pcs. $\left(X_{4}\right)$; 
- University income from income-generating activities, rub. $\left(X_{5}\right)$;

- Number of small innovative enterprises created on the basis of the university, pcs. $\left(X_{6}\right)$;

- Number of theses (candidate and doctoral) defended in the reporting year, pcs. $\left(X_{7}\right)$.

- A linear regression type was used to select indicators. It can be estimated which indicators of university performance have greater impact on the integral development index of the regions under consideration, using the selected indicators and focusing on the coefficient of determination calculated for each pair of dependent and independent variables. The variables with the coefficient of determination greater than or equal to $60 \%$ were selected as the ones with significant impact on the change in the dependent variable $(\mathrm{Y})$.

\section{RESULTS}

The results of calculating the integral index of innovation-driven growth in the Republic of Tatarstan indicate a gradual increase in the efficiency of innovative activities, but still there has been a decrease in the technical and economic conditions of innovation since 2016. This decrease can be explained by the deterioration of the economic situation in the state or by the lack of the need to improve the fixed assets of enterprises in the region (Figure 1).

Figure 1. Results of calculating the integral index of the innovation-driven growth in the Republic of Tatarstan, units.

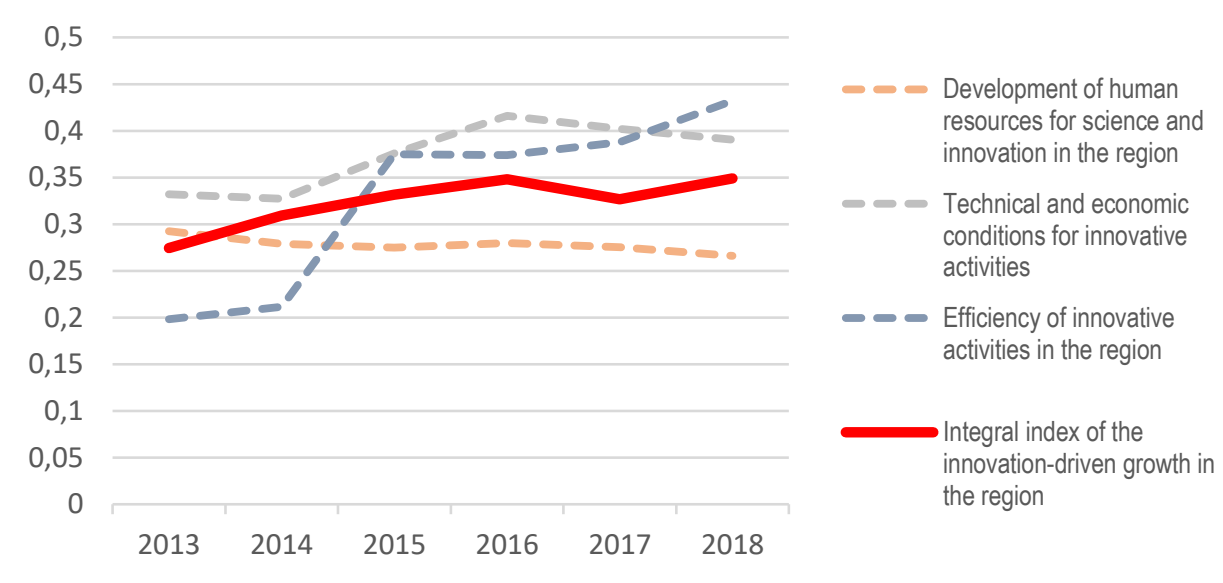

The next stage of the study was to identify the relationship between the calculated index of the innovation-driven growth in the Republic of Tatarstan and the activities of the Kazan National Research Technological University from 2013 to 2018. The coefficients of determination were calculated for each indicator describing the performance of the NRU; the most significant of them are presented in table 1.

Table 1. Coefficients of determination of the dependent variable $Y_{1}$ with the performance indicators of the Kazan National Research Technological University.

\begin{tabular}{ccc}
\hline & $\begin{array}{c}\text { Income from extrabudgetary } \\
\text { activities }\left(X_{5}\right)\end{array}$ & Small innovative enterprises $\left(X_{6}\right)$ \\
\hline Coefficient of determination $\left(R^{2}\right)$ & 0.5 & 0.72 \\
Resulting regression equation & $y=-4 * 10^{-11} x+0.3912$ & $y=0.0195 x-0.4083$ \\
\hline
\end{tabular}

Based on the coefficients of determination obtained in the course of the correlation analysis, it can be concluded that the greatest relationship with the change in the integral index of the innovation-driven growth in the Republic of Tatarstan is observed with indicators of income from extrabudgetary activities $\left(X_{5}\right)$ and the number of small innovative enterprises $\left(X_{6}\right)$. In this case, it can 
be concluded that the activities of small innovative enterprises and extrabudgetary activities of the Kazan National Research University are associated with changes in the indicators included in the calculated integral index. Therefore, it can be assumed that small enterprises operating as part of this university fulfill the tasks assigned to them, which confirms the authors' assumption made when analyzing the data obtained in the course of calculating the integral index of innovation-driven growth in the Republic of Tatarstan.

As such, the Republic of Tatarstan is now actively increasing the efficiency of innovative activities in the region, using the created infrastructure for the development of innovations. At the same time, the regional enterprises suffered from the consequences of changes in the economic situation in the country, which forced them to reduce the amount of funds spent on investment in fixed assets.

As evidenced by the obtained values, the innovative activities in the Irkutsk region are at a fairly low level. Besides, the values of the calculated integral index decreased when taking into account the block "Level of development of small innovative enterprises", which indicated the low performance of small innovative enterprises in the region. A decline in all indicators describing the development of infrastructure for promoting innovation has been observed in the region since 2014: a decline in indicators of the development of human resources for science and innovation, as well as the technical and economic conditions for innovation. The integral index of the innovationdriven growth of the Irkutsk region is falling against this background.

Despite the relatively stable situation with the efficiency of the innovative activities, which, unfortunately, are at a very low level, a further deterioration in the conditions for the development of innovations may contribute to the region's lagging behind the industry development trend (Figure 2).

Figure 2. Results of calculating the integral index of the innovation-driven growth in the Irkutsk region, units.

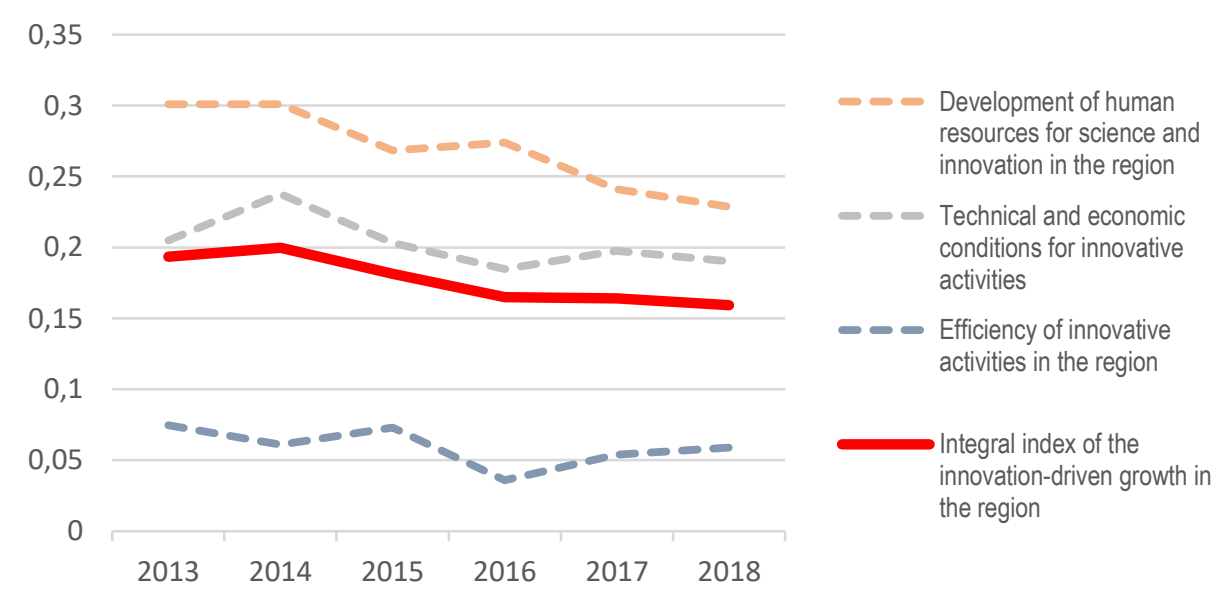

The authors review the role of the Irkutsk National Research Technical University in the development of the innovation area of the Irkutsk region. For this purpose, the coefficients of determination of indicators describing the activities of the university and the resulting integral index of the regional development are calculated (Table 2). 
Table 2. Coefficients of determination of the dependent variable $Y_{1}$ with the performance indicators of the Irkutsk National Research Technical University.

\begin{tabular}{cccc}
\hline & $\begin{array}{c}\text { Number of graduate } \\
\text { students }\left(X_{2}\right)\end{array}$ & R\&D volume $\left(X_{3}\right)$ & $\begin{array}{c}\text { Small innovative } \\
\text { enterprises }\left(X_{6}\right)\end{array}$ \\
\hline $\begin{array}{c}\text { Coefficient of } \\
\text { determination }\left(R^{2}\right)\end{array}$ & 0.89 & 0.97 & 0.68 \\
Regression equation & $y=0.0002 x+0.0967$ & $y=3 * 10^{-10} x+0.0937$ & $y=-0.0032 x+0.2835$ \\
\hline
\end{tabular}

Based on the resulting coefficients of determination, it can be assumed that the performance indicators of the university are associated with changes in the integral index of the innovationdriven growth in the Irkutsk region, because the indicators of the number of graduate students $\left(X_{2}\right)$, the R\&D volume $\left(X_{3}\right)$, and small innovative enterprises $\left(X_{6}\right)$ have a relationship with the change in the dependent variable $Y_{1}$. At the same time, the inverse relationship is observed with the number of small innovative enterprises created on the basis of the university - the lower is the value of the number of small innovative enterprises, the higher is the index of the innovation-driven growth in the region. This fact indicates the low performance of small enterprises at the university, despite the relationship with the change in the dependent variable $Y_{1}$.

As such, the Irkutsk region has a fairly low level of development of the innovation area, as evidenced by the indicators obtained when calculating the integral index. There is a decrease in the costs of training personnel and renewal of fixed assets with a very low efficiency of innovation in the region.

The authors proceed to the analysis of the results obtained when calculating the integral index of the innovation-driven growth in the Perm region. It can be concluded when evaluating the intermediate results of the calculated indices by blocks that there is a significant deterioration in conditions promoting the development of innovations in the region: human resources and technical and economic factors. As in the case of the previously considered regions, there has been a significant decrease in the costs of updating the fixed assets of enterprises since 2016. On the contrary, the efficiency of the innovative activities in the Perm region has demonstrated positive dynamics and increased significantly since 2014.

Figure 3. Results of calculating the integral index of the innovation-driven growth in the Perm region, units.

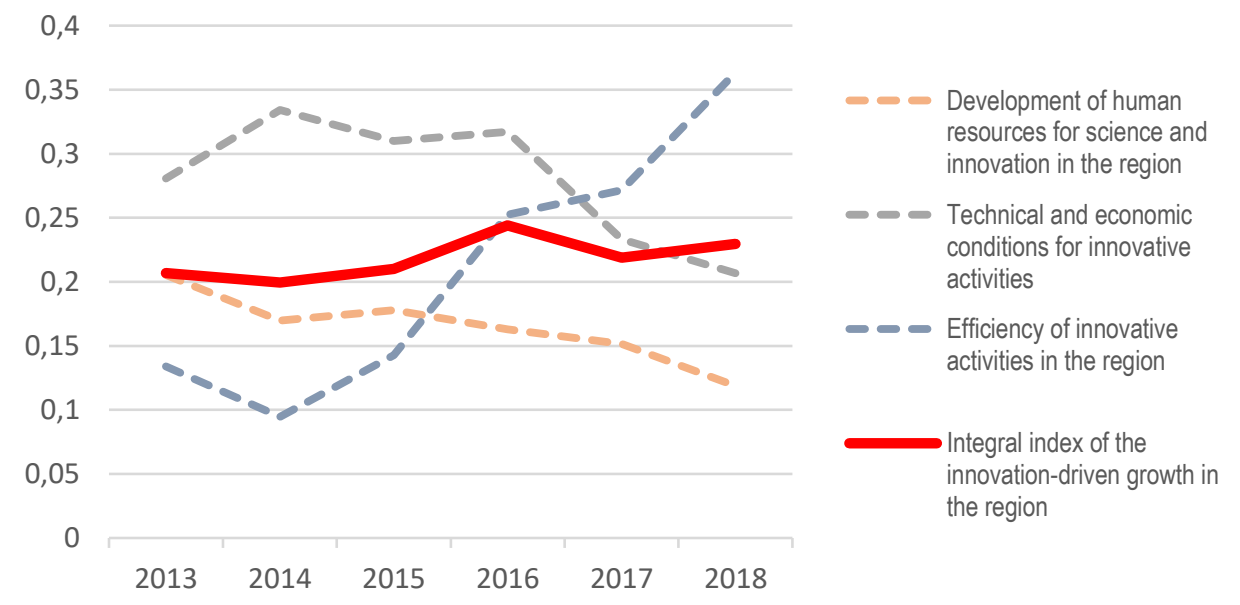

The analysis of the relationship between changes in indicators describing the activities of the Perm State National Research University and the calculated integral index of the innovation-driven growth in the Perm region revealed that none of the selected indicators had close relationship with the innovative activities in the region or influenced them. This fact indicated that the activities of 
the national university did not contribute to the creation of innovations in the region, while the created infrastructure and small innovative enterprises were not efficient in their operation.

As with the previously considered regions, let us analyze the results obtained for the Tomsk region and the Tomsk Polytechnic University. The calculated integral indices of the innovationdriven growth from 2013 to 2018 allowed to conclude that the innovation area in the Tomsk region was developing at a relatively high pace. At the same time, the block of indicators describing the efficiency of small innovative enterprises in the region did not have any negative impact - on the contrary, it developed at a fairly high pace, as evidenced by the difference between the calculated integral indices of the innovation-driven growth in the Tomsk region (Figure 4).

Figure 4. Results of calculating the integral index of the innovation-driven growth in the Tomsk region, units.

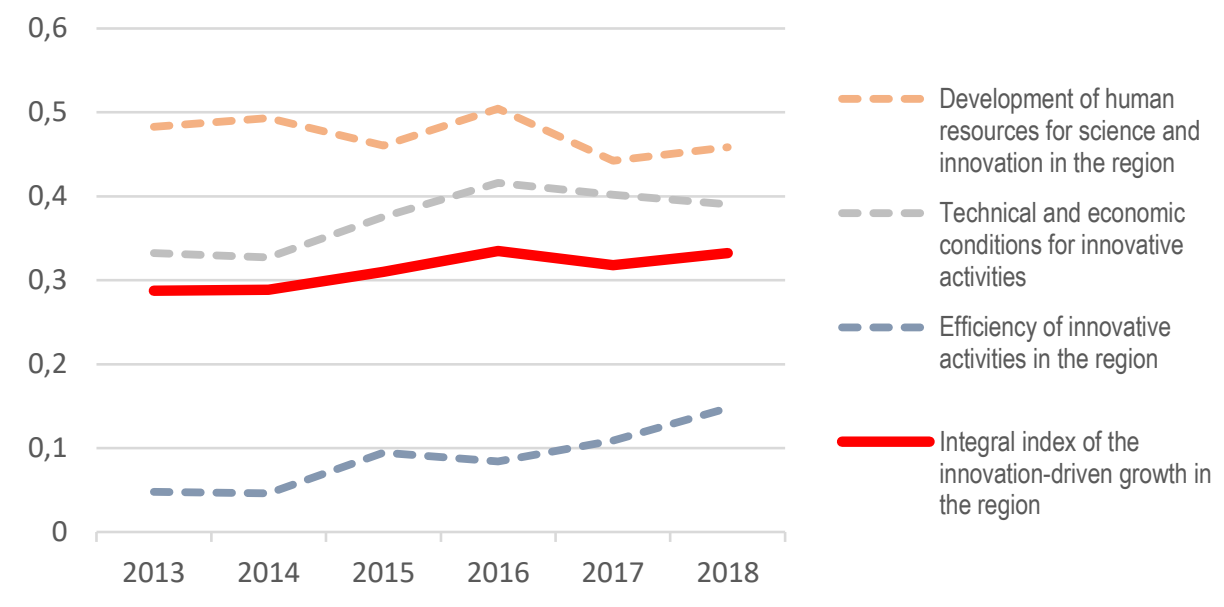

A large scientific base, represented by large universities, including the Tomsk Polytechnic University, has been created in the Tomsk region to contribute to the development of innovations in the region. The authors made an attempt to assess whether the activities of the national university were related to changes in the integral index of the development of innovations in the Tomsk region.

Table 3. Coefficients of determination of the dependent variable $Y_{1}$ with the performance indicators of the Tomsk Polytechnic University.

\begin{tabular}{cccc}
\hline & Number of students $\left(\mathrm{X}_{1}\right)$ & Number of patents $\left(\mathrm{X}_{4}\right)$ & $\begin{array}{c}\text { Number of theses } \\
\text { defended (candidate and } \\
\text { doctoral) }\left(\mathrm{X}_{7}\right)\end{array}$ \\
\hline $\begin{array}{c}\text { Coefficient of determination } \\
\left(\mathrm{R}^{2}\right)\end{array}$ & 0.81 & 0.58 & 0.77 \\
$\begin{array}{c}\text { Regression equation } \\
\text { d }\end{array}$ & $\mathrm{y}=-5^{*} 10^{-6} \mathrm{x}+0.3924$ & $\mathrm{y}=0.0007 \mathrm{x}+0.3896$ & $\mathrm{y}=0.0004 \mathrm{x}+0.3547$ \\
\hline
\end{tabular}

According to the calculated coefficients of determination for each of the indicators describing the activities of the Tomsk Polytechnic University, the number of students $\left(X_{1}\right)$, the number of patents $\left(X_{4}\right)$, and the number of theses defended (candidate and doctoral) $\left(X_{7}\right)$ have the greatest relationship with the change in the index of the innovation-driven growth in the Tomsk region. At the same time, the indicator of the number of students has an inverse relationship with the change in the integral index, which does not allow to conclude that it influences the change in the indicators describing the innovation area. As such, the R\&D carried out at the university, which ultimately lead to an increase in the number of patents and the number of defended candidate and doctoral theses, have positive impact on the innovation-driven growth in the Tomsk region. 
The authors consider the results of calculations of the integral index of the innovation-driven growth in the Belgorod region, where the Belgorod State National Research University is located. According to the data obtained, the Belgorod region does not observe high rates of innovation development, as evidenced by the values presented by blocks. According to the data, the development of human resources for science and innovation in the region is one of its strengths. The level of development of small innovative enterprises is also at an average level and its values are higher than in the blocks describing the efficiency of innovations and the technical and economic conditions of innovative activities.

Figure 5. Results of calculating the integral index of the innovation-driven growth in the Belgorod region, units.

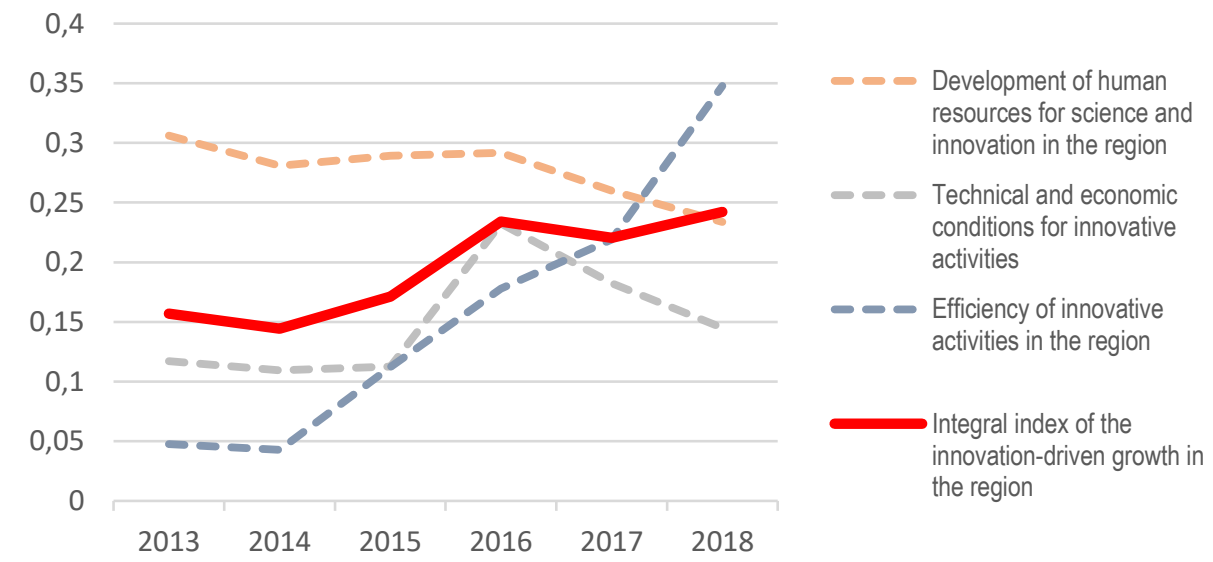

It can be seen from the data presented in figure 5 that there is a decrease in the rate of training the human resources for science and innovation in the region, as well as the technical and economic conditions of innovative activities. Despite this, there is a significant increase in the efficiency of innovative activities in the region, which ultimately influences the result of the integral index of the innovation-driven growth in the Belgorod region.

A significant role in the development of the innovation area in the Belgorod region has been assigned to the Belgorod State National Research University since 2018. As with the previously considered regions, the authors determine the relationship between the change in the indicators of the national university and the integral index of the innovation-driven growth in the Belgorod region.

Table 4. Coefficients of determination of the dependent variable $Y_{1}$ with the performance indicators of the Belgorod State University.

\begin{tabular}{cccc}
\hline & Number of students $\left(\mathrm{X}_{1}\right)$ & $\begin{array}{c}\text { Number of small } \\
\text { innovative enterprises } \\
\left(\mathrm{X}_{6}\right)\end{array}$ & $\begin{array}{c}\text { Number of theses } \\
\text { defended (candidate and } \\
\text { doctoral })\left(\mathrm{X}_{7}\right)\end{array}$ \\
\hline $\begin{array}{c}\text { Coefficient of determination } \\
\left(\mathrm{R}^{2}\right)\end{array}$ & 0.8605 & 0.8748 & 0.8206 \\
$\begin{array}{c}\text { Regression equation } \\
\mathrm{y}\end{array}$ & $\mathrm{y}=-2^{*}+10^{-5} \mathrm{x}+0.5582$ & $\mathrm{y}=0.005 \mathrm{x}+0.0082$ & $\mathrm{y}=0.0009 \mathrm{x}+0.1364$ \\
\hline
\end{tabular}

Indeed, the activities of the Belgorod State National Research University influence the innovation-driven growth in the Belgorod region, which is confirmed by the obtained coefficients of determination. The indicators of the number of small innovative enterprises $\left(X_{6}\right)$ and of the number of theses defended (candidate and doctoral) $\left(X_{7}\right)$ have the strongest relationship with the change in the integral index of the innovation-driven growth in the Belgorod region. The indicator of the number of students $\left(X_{1}\right)$ also has a close relationship with the change in the dependent variable, but 
this relationship is negative, which does not allow to conclude about the efficient influence of the number of students on the innovation-driven growth in the Belgorod region.

As such, the Belgorod region does not have a high level of the innovation-driven growth. Despite this, there is a gradual increase in the efficiency of innovative activities in the region, as evidenced by the integral index of the innovation-driven growth in the region obtained in the course of calculations. The activities of the Belgorod State National Research University are focused on the development of the innovation area, and small enterprises of the university and the results of research work influence the level of this development.

\section{DISCUSSION}

The assessment of the relationship between the innovation-driven growth in the regions of the Russian Federation and the activities of the NRUs on their territories has allowed to reveal the following trends:

1. Decrease in the efficiency of the indicators describing the activities of universities: there is a significant reduction in the areas of development of human resources, the efficiency of personnel training, research, and scientific activities. The Tomsk Polytechnic University demonstrated the highest performance among the national universities under consideration in 2013, while the Kazan National Research Technological University held the leading positions in terms of the efficiency of personnel training and scientific activities. The results calculated for 2018 clearly demonstrate the decline in the performance of most NRUs. The exception is the Belgorod State National Research University, which was able to significantly improve the efficiency of personnel training, human resources, and research activities. It must be noted that the university has been implementing the program "Belgorod State National Research University as a city-forming scientific, educational, innovative, production and sociocultural center of the Belgorod region for 2018 - 2022" since 2018, which became an impetus for development for the university.

2. Poor quality of implementation of the tasks set by the Government of the Russian Federation for the NRUs. For example, in accordance with the Concept of creating a network of the NRUs, they are described by an increased focus on research activities and supplying personnel to the priority areas for the development of science and economics in the regions of the Russian Federation. In the course of the study, the authors found that most national universities did not show high results in the innovation-driven growth in the region.

3. Decrease in the R\&D volume in research universities, which is firstly due to a decrease in state funding for these types of activities (more than $67 \%$ of research conducted at universities is now funded from the federal budget). The low popularity of research practice among university students is another reason for the decline in R\&D activities. Scientific activity in most universities is focused mainly on obtaining additional privileges in education, and teachers involved in R\&D consider these activities as routine.

4. The presence of the university among institutions with a high level of competitiveness in the world educational rankings contributes to the attraction of foreign students, teachers, and higher educational institutions involved in joint R\&D. However, the indicators that most universities strive for do not allow to develop all areas of the university's activities, which negatively influences the quality of training specialists for the regional labor market and the results of scientific research. For example, it can be noted that universities are actively working to increase the number of publications in the Russian Science Citation Index, Scopus, and Web of Science journals with low impact factor, while the number of citations of published articles is extremely low.

The lack of demand for NRU developments by regional enterprises and the lack of their direct interaction are among the largest problems. In this case, the most popular measure is the unification of organizations and educational institutions into a single educational or scientific cluster serving as the basis for their active interaction. Unfortunately, this mechanism can only be implemented with 
the help of the state, since many commercial organizations are interested in instant profit and do not focus on simplifying or modernizing production, or they believe that NRUs are far from reality. The state authorities of the regions of the Russian Federation, on the territory of which clusters or centers of innovation are created, should promote the active involvement of enterprises by providing them with tax incentives or additional payments. Focusing on the interaction between business and higher educational institutions will allow to use the infrastructure created on the basis of universities for the modernization of production of regional enterprises and breakthrough R\&D.

\section{CONCLUSION}

The system of higher education is currently being reformed in the Russian Federation, but this has not yet yielded significant results. It can be noted based on the experience of reforming the higher education system and territorial development of the countries of Europe and Asia that the main emphasis by the public authorities of all countries is placed on the creation of autonomous educational institutions capable of independently satisfying their needs and making a profit without additional state aid. For example, close attention when formulating a policy to encourage research activities at universities should be paid to the practice of the Japanese government, where the main cash flow is allocated not for the amount of research conducted, but for its quality and specifics of the development management. Unfortunately, targeted support for research conducted in Russia most often fails to yield the desired result, because it does not guarantee its payback and high quality.

The Zhejiang University and the Zhejiang Province have established the Zijin Innovation Town organization, aimed at transforming industry in the province, promoting the all-round development of innovation, and creating an entrepreneurial ecosystem. The state aid for the Province comes in the form of land, investment, and enterprise subsidies. In addition, the government cooperated with the university to establish a committee to govern this innovation town. The Zhejiang University provides open access to its research equipment for SMEs in order to support technological innovation in small and medium-sized enterprises. To do so, the university has created several clusters with enterprises and other universities, and is also trying to build service platforms in innovative design, $R \& D$, and artificial intelligence. This example perfectly demonstrates the efficiency of the participation of large universities in the cluster development, where not only state-owned companies take part, but also large, small, and medium-sized businesses interested in active interaction with the university.

Besides, the experience of monitoring research and innovative activities built in the European Union deserves special attention, as it allows universities to assess the degree of their influence on the innovation-driven growth of the region they are located in. Given that the activities of NRUs are aimed at encouraging innovation in the regions of Russia, this practice will allow for more efficient allocation of budgetary funds based on the efficiency of the university's innovative activities.

Authors' Contributions: Glebova, I. S.: conception and design, acquisition of data, analysis and interpretation of data, drafting the article, critical review of important intellectual content; Berman, S. S.: conception and design, acquisition of data, analysis and interpretation of data, drafting the article, critical review of important intellectual content; Abramov, R. A.: conception and design, acquisition of data, analysis and interpretation of data, drafting the article, critical review of important intellectual content; Lvov, I. N.: conception and design, acquisition of data, analysis and interpretation of data, drafting the article, critical review of important intellectual content. All authors have read and approved the final version of the manuscript.

Ethics Approval: Not applicable.

Acknowledgments: Not applicable. 


\section{REFERENCES}

Casper, S. (2013). The Spill-Over Theory Reversed: The Impact of Regional Economies on the Commercialization of University Science. Research Policy, 42, 1313-1324. https://doi.org/10.1016/j.respol.2013.04.005

Cooke, P. (2008). Regional Innovation Systems: Origin of the Species. The International journal of technological learning, innovation and development, 1, 393-409. https://doi.org/10.1504/ijtlid.2008.019980

Etzkowitz, H., \& Leydesdorff, L. (1999). The Future Location of Research and Technology Transfer. Journal of Technology Transfer, 24, 111-123. https://doi.org/10.1023/A:1007807302841

Etzkowitz, H., Webster, A., Gebhardt, C., \& Terra, B.R.C. (2000). The Future of the University and the University of the Future: Evolution of Ivory Tower to Entrepreneurial Paradigm. Research Policy, 29, 313-330. https://doi.org/10.1016/s0048-7333(99)00069-4

Gibbons, M., Limoges, C., Nowotny, H., Schwartzman, S., Scott, P., \& Trow, M. (1994). The New Production of Knowledge: The Dynamics of Science and Research in Contemporary Societies. London, Thousand Oaks, New Delhi: SAGE Publications, $179 \mathrm{p}$.

Goddard, J., \& Chatterton, P. (1999). Regional Development Agencies and the Knowledge Economy: Harnessing the Potential of Universities. Environment and Planning C: Government and Policy, 17(6), 685-699.

https://doi.org/10.1068/c170685

Goldstein, H. (2010). The "entrepreneurial turn" and regional economic development mission of universities. Annals of Regional Science, 44, 83-109. https://doi.org/10.1007/s00168-008-0241-z

Gunasekara, C. (2006). Reframing the Role of Universities in the Development of Regional Innovation Systems. Journal of Technology Transfer, 31, 101-113. https://doi.org/10.1007/s10961-005-5016-4

Holland, B. A. (2001). Toward a Definition and Characterization of the Engaged University. Metropolitan Universities, 2, 20-29.

Silva, L. R., Santos, A. R., \& Santos, I. T. R. (2020). Public policies for education of/in the field and the school environment in a settlement of the MST: the intimate relationship with the pedagogical policy. Journal of Research and Knowledge Spreading, 1(1), e11737. http://dx.doi.org/10.20952/jrks1111737

Power, D., \& Malmberg, A. (2008). The Contribution of Universities to Innovation and Economic Development: in what Sense a Regional Problem? Cambridge Journal of Regions, Economy and Society, 1(2), 233-245. https://doi.org/10.1093/cjres/rsn006

Trippl, M., Sinozic, T., Lawton Smith, H. (2015). The Role of Universities in Regional Development: Conceptual Models and Policy Institutions in the UK, Sweden and Austria. European Planning Studies, 23(9), 1722-1740.

https://doi.org/10.1080/09654313.2015.1052782

Uyarra, E. (2010). Conceptualizing the Regional Roles of Universities, Implications and Contradictions. European Planning Studies, 18, 1227-1246. https://doi.org/10.1080/09654311003791275

Received: 31 January 2021 | Accepted: 2 February 2021 | Published: 24 April 2021 